\title{
Аналіз операційних втручань при пошкодженнях ротаціӥної манжети плеча із застосуванням артроскопії
}

\author{
IU. M. PIVEN, I. V. KSONZ, IU. P. LYTVYN, O. V. PELYPENKO ${ }^{1}$, S. M. PAVLENKO
}

Higher State Educational Institution of Ukraine "Ukrainian Medical Stomatological Academy", Poltava State Institution "Dnipropetrovsk Medical Academy"

\section{ANALYSIS OF OPERATIVE INTERVENTIONS AT DAMAGES OF ROTATOR GUFF OF SHOULDER USING THE ARTHROSCOPY}

\begin{abstract}
У статті наведено результати лікування пошкоджень ротаційної манжети плеча у 72 хворих при використанні як малоінвазивної відкритої методики (61 пацієнт), так і при артроскопії (11 пацієнтів). Проведений аналіз показав: більше половини пацієнтів мали внутрішньосуглобові патології, поєднані 3 пошкодженням ротаційної манжети плеча; найбільш оптимальним початком операційного втручання є артроскопія, яка дозволяє діагностувати всі пошкодження плечового суглоба, а по можливості їх усунути. Малоінвазивне відкрите виправдане при тотальних розривах з відривом від місця інсеції ротаційної манжети плеча і в застарілих випадках при вираженій рефракції сухожильних частин.

The article adduces the results of treatment of damages of rotary cuff of shoulder, in 72 patients using of both little invasive open methodology (61 patients) and arthroscopy (11 patients). The conducted analysis showed: the more than half of patients had intra-articular pathologies combination with the damage of rotary cuff of shoulder; most optimal beginning of operative intervention from arthroscopy that allows to diagnose all damages of humeral joint, and at possibility and their removals. Little invasive open interference is justified at total breaks, with tearing away from the place of insertion of rotator cuff of shoulder and in inveterate cases at the expressed retraction of tendon parts.
\end{abstract}

Постановка проблеми і аналіз останніх досліджень та публікацій. Мобільність та міцність сухожильно-капсульного апаратаплечовогосуглоба, в склад якого входить ротаційна манжета плеча (РМП), є основою оптимального функціонування верхньої кінцівки [5]. Діапазон рухів, що виконується верхньою кінцівкою в плечовому суглобi, $\in$ в від надзвичайно різко напруженого (наприклад, підняття ваги над головою), до надзвичайно точного (наприклад, кидання дротика при грі в дартс). Продуктивна життєздатність людини залежить від повного безболісного об’єму рухів у плечовому суглобі.

Успіх лікування пацієнтів із пошкодженнями РМП являє собою проблему для лікарів у виборі методу лікування. Більшість, особливо в умовах поліклінічних відділень або в районних лікарнях, віддають перевагу консервативному лікуванню, в кращому випадку відкритому відновленню цілісності та реінсерції РМП, забуваючи при цьому про багатогранність даного типу ушкодження, підводячи все під один діагноз “розрив сухожилків”. Точна діагностика ушкодження структур плечового суглоба, функціональні вимоги хворого до кінцівки - все це є основними критеріями для досягнення найкращого результату лікуван- ня. Крім того, технічні навички, знання анатомічних особливостей плечового суглоба, а також розуміння в потребі відновлення при пошкодженні РМП потребують хірургічного досвіду, що далеко не кожен ортопед-травматолог може показати при лікуванні таких хворих.

В останнє десятиліття значно збільшилась кількість хворих із пошкодженням сухожильнокапсульного апарата плечового суглоба $[1,6,7]$. На нашу думку, це вписується в основні дві концепції (травматичну та диспластичну), що призводять до даного типу уражень [3], оскільки суспільство можна умовно поділити на дві групи. Першу, в якій люди ведуть так званий “здоровий спосіб життя”: починають займатись фітнесом, різними видами спорту, i, як наслідок, у більшості випадків виникає (аналіз причин отримання травми при зверненні хворого) некероване перевантаження сухожильно-капсульного апарата плечового суглоба (травматична концепція). Другу, в якій все кардинальнопротилежне: надмірна маса пацієнтів, зловживання алкоголем, куріння, що призводить, особливо у віці після 40 років, до дегенеративнодистрофічних змін сухожилків, і, як наслідок, незначна травма призводить до їх ушкодження (диспластична концепція). 
Велика кількість досліджень [1, 2, 3, 6, 7] з приводу такого типу пошкоджень все ще не дає чіткої відповіді у первинному виборі операційного втручання: артроскопічного чи відкритого малоінвазивного, а їх результати, незважаючи на значний науково-технічний прогрес у галузі медицини, залишаються ще далекими від ідеальних у функціональному відновленні верхньої кінцівки та боротьбі із больовим синдромом.

Все це, в свою чергу, впливає на працездатність пацієнта, порушує його сон, знижує якість життя хворого, а також виключає його як повноцінного працівника суспільства.

Отже, потрібен пошук комплесу пошкоджень сухожильно-капсульного апарата плечового суглоба, а, виходячи з цього, і вибір правильного методу лікування.

Мета роботи: покращити результати лікування, зокрема відновити функціональність верхньої кінцівки, об'єм рухів у плечовому суглобі, зменшити розвиток посттравматичного артрозу, зменшити строки непрацездатності, знизити відсоток виходу на інвалідність хворих шляхом розробки системи комплексного лікування, що базується на правильній діагностиці пошкоджень сухожильнокапсульного апарата плечового суглоба і виборі адекватної тактики лікування із розумінням анатомічних аспектів даної ділянки.

Матеріали і методи. Починаючи з 2008 року і до сьогодні, групу, яку досліджували, склали 72 пацієнти, оперовані як відкритим малоінвазивним методом, так і з 2012 року із застосуванням артроскопії. Пацієнти мали розрив РМП від малого до тотального з відривом від місць інсерції, що діагностували, використовуючи ультразвукове дослідження, а в деяких випадках магнітно-резонансну томографію в передопераційній підготовці.

Вік пацієнтів - від 28 до 80 років (середній вік 54 роки). Чоловіків було 42, жінок - 30.

61 хворий оперований за малоінвазивною відкритою методикою відновлення цілісності, реінсерції ротаційної манжети плеча з використанням анкерних фіксаторів, 11 пацієнтів оперовано з використанням анкерної фіксації і відновленням цілісності сухожильно-капсульного апарата плечового суглоба при застосуванні артроскопії.

Операційна техніка.

Малоінвазивне відкрите втручання. Використовуємо прийнятий SICOT (2005) доступ від акроміона між I та II порціями дельтоподібного м'яза розміром 4-5 см. Проводимо часткове видалення підакроміально-піддельтоподібної бурси, декомпресію підакроміального простору. Після встановлення пошкодження ротаційної манжети плеча проводимо обробку країв сухожильного розриву, відновлення ії цілісності, а за необхідності реінсерцію при використанні анкерної фіксації.
Рану ушиваємо пошарово 3 використанням активного дренування. Кінцівку тримаємо м'якою фіксуючою пов'язкою з аксіальною кутовою $15^{\circ}$ вставкою.

При використанні артроскопії. Використовуємо загальноприйняті порти доступу до плечового суглоба та ротаційної манжети плеча від 2 до 3. Проводимо часткове видалення підакроміальнопіддельтоподібної бурси, декомпресію підакроміального простору. Обов'язковим вважаємо виконання внутрішньосуглобової ревізії. При знаходженні внутрішньосуглобових пошкоджень проводимо їх усунення. Дебридмент країв розірваних сухожильних частин, відновлення цілісності ротаційної манжети плеча при використанні анкерної фіксації. Віддаємо перевагу двохрядному шву [1].

Шви на шкіру з використанням підм'язового активного дренування. Кінцівку тримаємо м'якою фіксуючою пов'язкою $з$ аксіальною кутовою $15^{\circ}$ вставкою.

3 першого дня в обох випадках після операції розпочинаємо лікувальні фізичні вправи, спрямовані на збереження пасивних рухів у плечовому суглобі, а також на збереження активних рухів у ліктьовому та кистьовому суглобах.

Термін спостереження в післяопераційному періоді склав від 1 місяця до 1 року.

У післяопераційному періоді для визначення відновлення функції верхньої кінцівки використовували шкалу Oxford shoulder score [4].

Результати досліджень та їх обговорення. Результати лікування представлено в таблицях 1 та 2.

За нашими спостереженнями, при порівнянні результатів лікування встановлено таке.

При використанні малоінвазивного відкритого відновлення цілісності РМП при малих та середніх розривах унеможливлюється ревізія суглобової порожнини, що, в свою чергу, може викликати недіагностовані, а значить, і не проліковані внутрішньосуглобові пошкодження.

Використання артроскопії дає можливість провести обстеження порожнини суглоба. За нашими спостереженнями, було виявлено розволокнення сухожилка довгої головки двоголового м'яза у 5 хворих, SLAP пошкодження в 1 хворого, ворсинчастий капсуліт в 1 хворого у поєднанні з розривом РМП. Отже, більше половини пацієнтів мали ускладнену патологію.

Втім, слід зазначити, що використання артроскопічного втручання найбільш оптимальне при малих та середніх розривах РМП та у свіжих випадках. При тотальних розривах з відривом від місця інсерції РМП та при значній ретракції сухожильних частин, застарілих пошкодженнях досить проблематично провести відновлення при використанні артроскопа. Тому в таких випадках віддаємо перевагу відкритому малоінвазивному методу. 
Таблиця 1. Результати лікування

\begin{tabular}{|c|c|c|c|c|c|}
\hline \multirow[t]{2}{*}{ Результат } & $\begin{array}{c}\text { Больовий синдром в } \\
\text { післяопераційному } \\
\text { періоді після за- } \\
\text { стосування } \\
\text { малоінвазивного } \\
\text { втручання } \\
\text { (1,5 міс.) }\end{array}$ & $\begin{array}{c}\text { Больовий синдром в } \\
\text { післяопераційному } \\
\text { періоді після } \\
\text { застосування } \\
\text { артроскопічного } \\
\text { втручання } \\
\text { (1,5 міс.) }\end{array}$ & $\begin{array}{c}\text { Обмеження рухів у } \\
\text { плечовому суглобі в } \\
\text { післяопераційному } \\
\text { періоді після засто- } \\
\text { сування малоінва- } \\
\text { зивного втручання } \\
\text { (2 міс.) }\end{array}$ & $\begin{array}{c}\text { Обмеження рухів у } \\
\text { плечовому суглобі в } \\
\text { післяопераційному } \\
\text { періоді після засто- } \\
\text { сування артро- } \\
\text { скопічного втручання } \\
\text { (2 міс.) }\end{array}$ & Загалом \\
\hline & 17 & 2 & 10 & 1 & 30 \\
\hline
\end{tabular}

Таблиця 2. Результати лікування

\begin{tabular}{||l|c|c|c||}
\hline \multicolumn{1}{||}{ Результат } & $\begin{array}{c}\text { У віддаленому післяопераційному } \\
\text { періоді після застосування } \\
\text { малоінвазивного втручання }\end{array}$ & $\begin{array}{c}\text { У віддаленому післяопераційному } \\
\text { періоді після застосування } \\
\text { артроскопічного втручання }\end{array}$ & Загалом \\
\hline Відмінно & 34 & 8 & 42 \\
\hline Добре & 21 & 2 & 23 \\
\hline Задовільно & 5 & 1 & 6 \\
\hline Незадовільно & 1 & - & 1 \\
\hline Загалом & 61 & 11 & 72 \\
\hline \hline
\end{tabular}

Для запобігання недіагностуванню поєднаних патологій вважаємо за доцільне при будь-якому пошкодженні РМП розпочинати з артроскопічної інспекції порожнини суглоба.

На нашу думку, відновлення лише анатомічної цілісності РМП, не враховуючи можливі поєднані патології, призводить до больового синдрому та функціональних обмежень верхньої кінцівки у віддаленому післяопераційному періоді. Все це стає причиною додаткового лікування пацієнтів (застосування нестероїдних протизапальних засобів, введення кортикостероїдів у віддаленому післяопераційному періоді, затягнення реабілітації); подовженої непрацездатності хворих.

Висновки. 1. Неможливо при використанні малоінвазивного відкритого відновлення цілісності РМП, особливо при розривах без відриву від місця інсерції, діагностувати внутрішньосуглобові пошкодження сухожильно-капсульного апарата пле-

\section{СПИСОК ЛІТЕРАТУРИ}

1. Сергієнко Р. О. Результати артроскопічного шва РМП. Переваги дворядної методики / Р. О. Сергієнко, О. В. Долгополов, О. С. Страфун // Лікування травм та захворювань верхньої кінцівки : матеріали науково-практичної конференції з міжнародною участю. - К., 2012. - С. 80-82.

2. Страфун С. С. Артроскопія в діагностиці та лікуванні захворювань та пошкоджень плечового суглоба / С. С. Страфун, Р. О. Сергієнко, О. В. Долгополов // Лікування травм верхньої кінцівки та їх наслідків : матеріали науково-практичної конференції з міжнародною участю. - К., 2007. - С. 76-77.

3. Тяжелов А. А. Вращательная манжета плеча / А. А. Тяжелов, Л. Д. Гончарова. - Харьков-Донецк : Крокус, 2007. -238 c. чового суглоба, які в подальшому стають причиною больового синдрому та неповного відновлення функціональності верхньої кінцівки у хворих.

2. Малоінвазивний відкритий метод виправданий при тотальних розривах з відривом від місця інсерції РМП та в застарілих випадках при вираженій ретракції сухожильних частин.

3. Застосування відновлення цілісності РМП при використанні артроскопії найбільш виправдане при малих та середніх розривах.

4. У будь-якому випадку розривів сухожильнокапсульного апарата плечового суглоба найбільш оптимальним $є$ початок операційного втручання 3 артроскопії, завдяки якій визначаються всі пошкодження плечового суглоба, а по можливісті і їх усунення.

5. Даний обгрунтований підхід до лікування пошкоджень РМП дозволяє зменшити період реабілітації в післяопераційному періоді та знизити термін непрацездатності хворих.

4. Dawson J. The Oxford Shoulder Score Revisited / J. Dawson, K. Rogers, R. Fitzpatrick // Archives of Orthopaedic Trauma Surgery. - 2009. - Vol. 129, № 1. - P. 119-123.

5. Lugo R. Shoulder Biomechanics / R. Lugo, P. Kung, C. B. Ma // European Journal of Radiology. - 2008. - № 68. - P. 16-24.

6. Bishop J. Cuff integrity after arthroscopic versus open rotator cuff repair: A prospective study / J. Bishop, S. Klepps, I. K. Lo // Journal of Shoulder and Elbow Surgery. - 2006. - Vol. 15, № 3. - P. 78-85.

7. Boileau B. Arthroscopic Repair of Full-Thickness Tears of the supraspinatus: Does the tendon Really Heal? / B. Boileau, N. Brassart, D. Watkinson // Journal Bone Joint Surgery (Am.). 2005. - № 87. - P. 1229-1240.

Отримано 05.10.15 